\title{
PELANGGARAN PRINSIP KESOPANAN DAN PRINSIP KERJA SAMA PADA PELAYANAN PENGUNJUNG DI HERO SUPERMARKET EMERALD BINTARO (KAJIAN PRAGMATIK)
}

\author{
Intan Rahmawati ${ }^{1}$ dan Tri Pujiati ${ }^{2}$ \\ Universitas Pamulang ${ }^{1}$ \\ Universitas Pamulang ${ }^{2}$ \\ intanrahmawaty2@gmail.com ${ }^{1}$ \\ tpujiati.unpam@gmail.com²
}

\begin{abstract}
Abstrak
Penelitian ini bertujuan untuk (1) menjelaskan bentuk pelanggaran prinsip kesopanan dalam tuturan antara karyawan Hero Supermarket Emerald Bintaro terhadap pengunjung; (2) memaparkan strategi kesopanan yang seharusnya dilakukan oleh karyawan Hero Supermarket Emerald Bintaro terhadap pengunjung; (3) menjelaskan bentuk pelanggaran prinsip kerja sama dalam tuturan antara karyawan Hero Supermarket Emerald Bintaro terhadap pengunjung. Metode yang digunakan dalam penelitian ini adalah metode deskriptif kualitatif. Berdasarkan analisis data, ditemukan bahwa (1) terdapat pelanggaran prinsip kesopanan yang dilakukan oleh karyawan Hero Supermarket Emerald Bintaro diantaranya (a) pelanggaran maksim kebijaksanaan sebanyak tujuh data, (b) pelanggaran maksim kebijaksanaan dan maksim penghargaan sebanyak dua data, (c) pelanggaran maksim kebijaksanaan dan maksim pemufakatan sebanyak dua data, (d) pelanggaran maksim pemufakatan sebanyak satu data dan (e) pelanggaran maksim kesederhanaan sebanyak satu data; (2) strategi kesopanan yang dilakukan oleh karyawan Hero Supermarket Emerald Bintaro mencakup dua strategi kesopanan yaitu strategi kesopanan positif dan kesopanan negatif, (a) pada kesopanan positif pelayan memberikan tindakan pengarahan berupa tuturan-tuturan yang bersifat mengarahkan pelanggan, (b) pada kesopanan negatif pelayan memberikan tindakan penawaran kepada pelanggan; (3) pada pelanggaran prinsip kerja sama, terdapat beberapa pelanggaran maksim yakni pelanggaran maksim kuantitas terdapat satu data, pelanggaran maksim relasi terdapat dua data, pelanggaran maksim cara terdapat empat data dan terdapat beberapa data yang mengandung keberhasilan prinsip kerja sama yakni lima data.
\end{abstract}

Kata kunci : Pelanggaran Prinsip Kesopanan, Prinsip Kerjasama.

\section{A. Pendahuluan}

Bahasa memegang peran penting dalam kehidupan manusia. Suatu kenyataan bahwa manusia mempergunakan bahasa sebagai komunikasi vital di dalam kehidupan. Bahasa merupakan salah satu ciri pembeda utama antara manusia dengan makhluk hidup yang lainnya. Aktivitas yang rutin selalu dipenuhi dengan bahasa antar anggota masyarakat. Pemilihan penggunaan bahasa yang baik dan benar dalam proses interaksi 
dan komunikasi, dapat mencerminkan sikap serta perilaku seseorang. Seseorang bahkan harus mampu memahami penggunaan bahasa yang sesuai dengan keadaan lingkungan serta memahami karakter dari lawan tutur itu sendiri.

Proses komunikasi bahasa yang dilakukan oleh penutur terhadap tuturannya berkaitan dengan pemilihan diksi oleh penutur demi terciptanya proses kebahasaan yang bersifat sopan dan bijaksana. Penggunaan bahasa berskala kecil telah banyak dilakukan orang tanpa melibatkan kehidupan sosial yang sebenarnya. Namun, kebanyakan yang dikatakan oleh penutur, dan sebagian besar yang dikomunikasikannya ditentukan oleh hubungan sosial. Kesalahan pemilihan bahasa akan berdampak pada citra diri bagi penutur itu sendiri sehingga dalam berkomunikasi kita perlu menggunakan tuturan yang sopan dan tidak menyinggung lawan tutur.

Melihat fenomena kebahasaan di atas, peneliti tertarik untuk meneliti fenomena pelanggaran prinsip kesopanan dalam tuturan yang terjadi antara penutur dan lawan tutur. Peneliti tertarik meneliti mengenai pelanggaran prinsip kesopanan tuturan karyawan-karyawan Hero Supermarket Emerald Bintaro mengenai pelayanannya terhadap pelanggan. Supermarket merupakan tempat terjadinya pertemuan antar individu yang berlatarbelakang memiliki sifat dan pemikiran yang berbeda.

\section{B. Kajian Pustaka}

Menurut Tarigan (2015 : 3), bahasa merupakan suatu sistem yang sistematis, barangkali juga untuk sistem generatif. Selain itu, bahasa juga merupakan seperangkat lambang-lambang mana suka atau simbol-simbol arbitrer. Lambang-lambang tersebut terutama sekali bersifat vokalis tetapi mungkin juga bersifat visual. Lambang itu juga bersifat konvensional. Kehidupan manusia tidak terlepas atas peran orang lain, sehingga manusia dapat dikatakan sebagai makhluk sosial atau makhluk yang tidak dapat berdiri sendiri. Proses interaksi antar manusia diperlukan untuk proses komunikasi sehingga dihasilkan sebuah tuturan. Kajian tuturan erat kaitannya dengan salah satu cabang ilmu linguistik yaitu pragmatik. Menurut Yule (2014 : 3), pragmatik adalah studi tentang makna yang disampaikan oleh penutur dan ditafsirkan oleh pendengar. Sebagai akibatnya studi ini lebih banyak berhubungan dengan analisis tentang apa yang dimaksudkan orang dengan tuturan-tuturannya daripada dengan makna terpisah dari 
kata atau frasa yang digunakan dalam tuturan itu sendiri. Jadi, dapat dikatakan bahwa ilmu ini mengkaji tentang maksud yang disampaikan oleh penutur.

Menurut Tarigan (2009:35) bahwa prinsip kerja sama dibagi menjadi:

1. Maksim kuantitas yaitu penutur memberikan jumlah informasi yang tepat pada mitra tutur.

2. Maksim kualitas yaitu penutur membuat kontribusi yang benar kepada mitra tutur.

3. Maksim relasi yaitu menjaga kerelevansian tuturan.

4. Maksim cara yaitu mentajamkan pikiran.

Selain itu, menurut Tarigan (2009:36) bahwa prinsip kesantunan dibagi menjadi:

1. Maksim kebijaksanaa yaitu memperhatikan untung dan rugi dalam tuturan.

2. Maksim kedermawanan yaitu memperhatikan keuntungan pihak mitra tutur.

3. Maksim penghargaan yaitu memperhatikan ekspresi dan asersi dalam tuturan yang memperhatikan perasaan.

4. Maksim kesederhanaan yaitu memperhatikan ekspresi dan asersi dalam tuturan.

5. Maksim simpati yaitu memperhatikan rasa simpati kepada mitra tutur.

\section{Metode Penelitian}

Metode penelitian merupakan cara mengemukakan secara teknis tentang metode-metode yang digunakan oleh penelitinya. Dalam penelitian ini, peneliti menggunakan metode berupa deskriptif kualitatif. Hal ini disebabkan data-data dalam penelitian ini berupa deskripsi tuturan karyawan Hero Supermarket Emerald Bintaro yang mengandung nilai kesantunan dan proses kerja sama yang terjalin antara penutur dan lawan tutur.

\section{Analisis Dan Pembahasan}

\section{Pelanggaran Maksim Kebijaksanaan}

Menurut Leech (dalam Tarigan, 2015 : 36), maksim kebijaksanaan adalah maksim yang berbicara tentang kerugian dan keuntungan. Inti pokok dari maksim kebijaksanaan adalah "kurangi atau perkecilah kerugian kepada orang lain // tambahi 
atau perbesarlah keuntungan kepada orang lain.". Berikut ini merupakan hasil analisis pelanggaran maksim keijaksanaan yang terdapat pada ata 001.

\section{Data 001}

$\begin{array}{ll}\text { Kasir } & \text { : "Ibu ada lagi yang lainnya?" } \\ \text { Pelanggan } & \text { :"Sama kinder joy satu." } \\ \text { Kasir } & \text { : "Mau pake plastik?" } \\ \text { Pelanggan } & \text { : "Nggak usah." } \\ \text { Kasir } & \text { : "Jadi tiga belas ribu lima ratus." }\end{array}$

Konteks tuturan dari data tersebut adalah seorang pelanggan yang hendak membayarkan belanjaannya ke kasir dan seorang kasir tanpa salam pembuka dan langsung menanyakan apakah ada yang ingin ditambah dari belanjaan pelanggan tersebut. Pelanggan menjawab dengan singkat tambahan belanjaannya berupa salah satu makanan ringan yang diberikan kepada kasir tersebut. Selanjutnya kasir memberikan penawaran untuk menggunakan kantong plastik, tetapi pelanggan menolaknya karena jumlah belanjaan pelanggan tersebut hanya sedikit. Kasir menyebutkan jumlah nominal belanjaan pelanggan tersebut sebanyak tiga belas ribu lima ratus rupiah dan pelanggan memberikan sejumlah uang sebagai bahan pembayaran. Transaksi selesai dengan kasir menutup drawer mesin kasir dan pelanggan meninggalkan lokasi kasir tersebut. Dialog ini terjadi pada tanggal 10 Oktober 2016 pukul 16.25 WIB.

Interpretasi dari tuturan data di atas menunjukkan adanya pelanggaran prinsip kesopanan yang dilakukan oleh seorang kasir dalam hal pelayanan. Pada tuturan pertama yang menyatakan "Ibu ada lagi yang lainnya?", kasir tersebut tidak melakukan salam pembuka (greeting) kepada pelanggan. Hal ini menyalahi prosedur yang seharusnya diterapkan oleh karyawan khususnya divisi kasir dalam melayani pelanggan. Kesalahan tersebut terjadi dikarenakan pada saat itu kondisi kasir yang sedang antre dan kasir tersebut juga terlihat sedang terburu-buru dalam melakukan pekerjaannya sehingga tidak ada proses sapa diawal pembuka dialog dengan pelanggan. Pada tuturan ketiga yang menyatakan "Mau pake plastik?" juga merupakan sebuah pelanggaran prinsip kesopanan. Kasir tersebut melakukan penawaran yang tidak diketahui maksud dari apa yang ditawarkan. Selain itu, kasir juga tidak menginformasikan mengenai plastik berbayar kepada pelanggan dan hal tersebut dapat memberikan kerugian besar kepada pelanggan. Tuturan kelima yang menyatakan "Tiga belas ribu lima ratus" merupakan penjabaran kasir mengenai total belanja pelanggan tersebut. Tuturan kasir 
tersebut juga mengandung pelanggaran prinsip kesopanan karena sasaran tuturan dari kasir tersebut lebih dari satu. Dalam hal ini, pelanggan membeli sejumlah barang dan kasir hanya menyebutkan satu harga saja tanpa menjelaskan total semua dari belanjaan pelanggan tersebut. Hal tersebut dapat memicu ketimpangan informasi terhadap pelanggan mengenai total belanjaannya.

\section{Pelanggaran Maksim Kebijaksanaan dan Maksim Penghargaan}

Menurut leech (dalam Tarigan, 2015 : 36), maksim kebijaksanaan adalah maksim yang berbicara tentang kerugian dan keuntungan. Inti pokok dari maksim kebijaksanaan adalah "kurangi atau perkecilah kerugian kepada orang lain // tambahi atau perbesarlah keuntungan kepada orang lain.”. Sedangkan maksim penghargaan adalah maksim yang berbicara tentang ekspresi dan asersi atau dalam perasaan dan ketegasan. Inti pokok dari maksim penghargaan adalah "adalah "kurangi cacian pada orang lain // tambahilah pujian bagi orang lain.”. Berikut ini merupakan hasil analisis pelanggaran maksim kebijaksanaan dan maksim penghargaan yang terdapat pada data 008.

\section{Data 008}

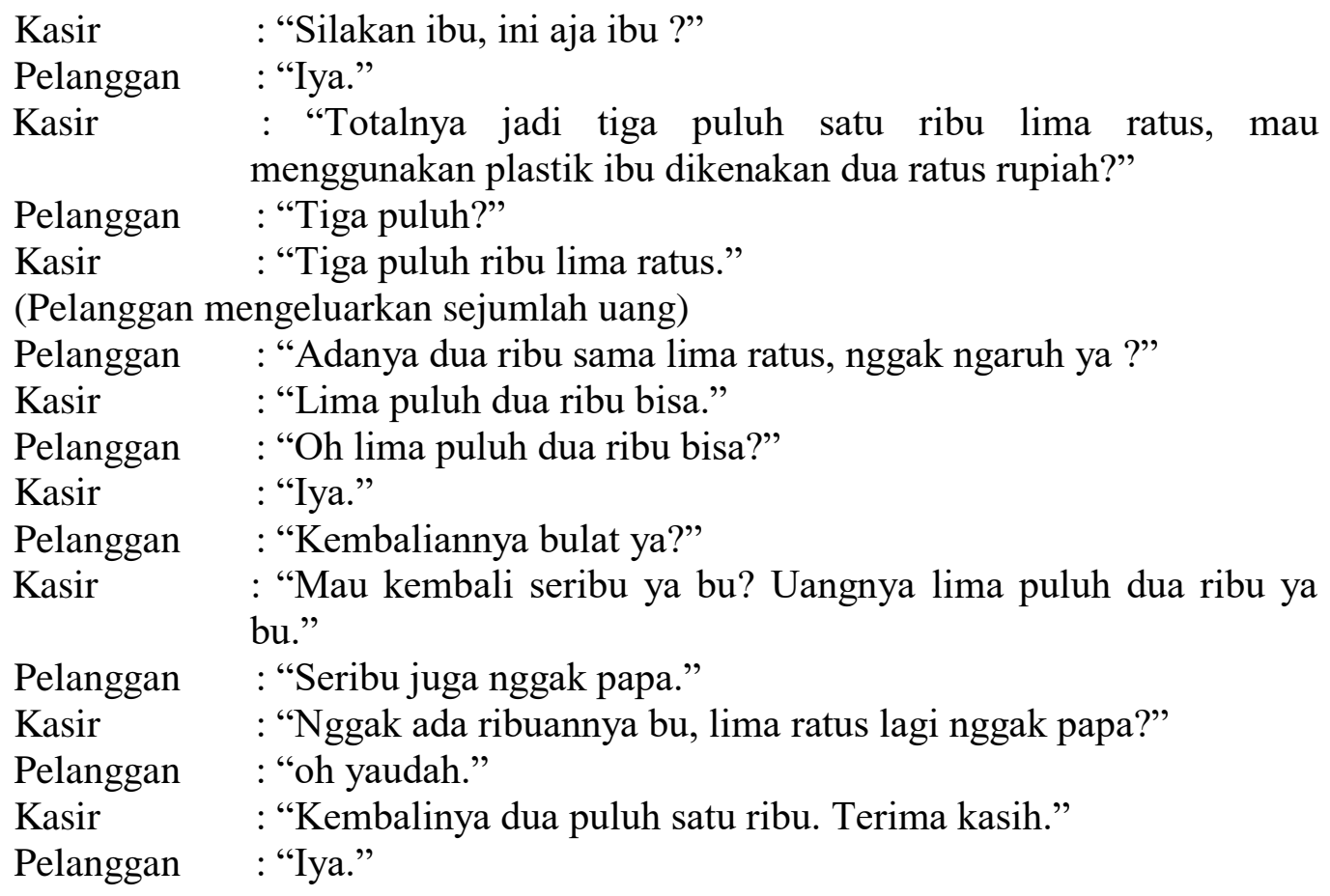

Konteks tuturan pada data di atas adalah seorang pelanggan yang hendak membayarkan sejumlah belanjaannya ke kasir, kemudian kasir tidak memberikan salam hanya memberikan sapaan singkat kepada pelanggan tersebut. Selanjutnya, kasir 
tersebut memberikan penawaran kepada pelanggan untuk menggunakan plastik berbayar, pada proses penawaran tersebut, kasir memberikan sedikit informasi mengenai plastik berbayar dan informasi mengenai total keseluruhan belanjaan pelanggan tersebut. Kemudian pelanggan tidak menghiraukan penawaran dari kasir tersebut dan langsung mengeluarkan sejumlah uang dengan menanyakan kembali total harga belanjaannya. Kemudian pelanggan mengeluarkan kembali sejumlah uang dengan maksud agar kasir tidak memberikan uang receh kepada pelanggan tersebut, pelanggan mengeluarkan uang dua ribu rupiah dan lima ratus rupiah. Kondisi kasir pada saat itu tidak memiliki uang kertas atau dalam arti kasir akan memberikan sejumlah kembalian dengan uang receh kembali. Kasir bermaksud memberikan penolakan terhadap uang tambahan yang diberikan oleh pelanggan tersebut, namun kasir berusaha menghargai usaha pelanggan tersebut. Selanjutnya, pelanggan kembali meminta agar kembalian yang akan diterimanya adalah uang yang bulat bukan uang receh. Akan tetapi, kasir tidak dapat memenuhi maksud permintaan dari kasir tersebut dan pada akhirnya pelanggan tersebut menerima apapun yang diberikan oleh kasir. Transaksi ditutup dengan ucapan terima kasih dari kasir sebagai salam penutup dalam proses transaksi tersebut. dialog ini terjadi pada tanggal 10 Oktober 2016 pada pukul 18.19 WIB.

Interpretasi percakapan yang tertera pada data di atas menunjukkan adanya pelanggaran prinsip kesopanan yang dilakukan oleh seorang kasir terhadap pelayanan yang dilakukan terhadap pengunjung. Pada dialog kasir yang pertama yang menunjukkan adanya kegiatan pembuka pembicaraan, seorang kasir menuturkan "Silakan ibu. Ini aja ibu?". Tuturan tersebut dianggap melanggar prinsip kesopanan karena kasir tidak melakukan salam pembuka sebagai tindakan fatis atau pembuka pembicaraan. Aturan Hero Supermarket yang mengharuskan semua divisi untuk mengucapkan salam pembuka sebagai proses awal melakukan interaksi dengan pengunjung atau pelanggan dalam hal ini tidak dilakukan oleh seorang kasir. Kata "Silakan" merupakan kata yang kurang pantas dijadikan sebagai salam pembuka bagi divisi kasir. Selanjutnya pada pertanyaan kasir yang bertujuan mempertegas proses akhir belanja pelanggan tersebut yang menyatakan “ini aja ibu?" juga dianggap sebagai pelanggaran prinsip kesopanan. Penggunaan kata "ini” dan disandingkan dengan kata “aja (saja)" menunjukkan sikap meremehkan yang dilakukan kasir terhadap jumlah belanjaan yang dibayarkan pelanggan tersebut. 
Pada tuturan kasir yang kedua yang menyatakan "Totalnya jadi tiga puluh satu ribu lima ratus, mau menggunakan plastik ibu dikenakan dua ratus rupiah?", tuturan tersebut juga dianggap melanggar prinsip kesopanan. Tindakan kasir yang bersifat informatif mengenai penggunaan plastik berbayar sudah tepat dilakukan karena kasir telah memberikan informasi kepada pelanggan bahwa penggunaan kantong plastik akan dikenakan biaya, akan tetapi tindakan tersebut hanya akan memberikan keuntungan kepada pihak kasir karena kasir tidak memberikan solusi atau alternatif dari penggunaan plastik berbayar.

Selanjutnya pada tuturan kasir yang keenam yang menyatakan "mau kembalian seribu ya bu?", tuturan tersebut juga mengandung pelanggaran prinsip kesopanan. Konteks tuturan tersebut merupakan jawaban atas pertanyaan pelanggan yang memberikan sejumlah uang tambahan yang bertujuan agar kasir tidak memberikan uang recehan kepada pelanggan tersebut. jawaban tersebut tidak seharusnya disampaikan kepada kasir, karena kasir tersebut sudah paham akan maksud dari pelanggan tersebut dan apabila tuturan tersebut diucapkan seperti halnya yang dilakukan kasir tersebut akan memberikan dampak bahwa pelanggan akan merasa malu terhadap tindakannya atau dianggap meremehkan uang recehan.

Selanjutnya pada tuturan kasir yang ketujuh yang menyatakan "nggak ada ribuannya bu, lima ratus lagi nggak papa?", tuturan tersebut juga dianggap melanggar prinsip kesopanan karena tindakan kasir yang tidak memberikan keuntungan kepada pelanggan terhadap keinginan pelanggan. Konteks tuturan tersebut adalah keinginan pelanggan agar kasir memberikan kembalian berupa uang kertas, sedangkan keadaan kasir tidak dapat memberikan uang kertas. Tuturan tersebut tidak menunjukkan adanya sifat pengorbanan dari kasir terhadap keinginan atau maksud dari pelanggan tersebut.

\section{Pelanggaran Maksim Kebijaksanaan dan Maksim Pemufakatan}

Menurut leech (dalam Tarigan, 2015 : 36), maksim kebijaksanaan adalah maksim yang berbicara tentang kerugian dan keuntungan. Inti pokok dari maksim kebijaksanaan adalah "kurangi atau perkecilah kerugian kepada orang lain // tambahi atau perbesarlah keuntungan kepada orang lain.”. Sedangkan maksim pemufakatan adalah maksim yang berbicara tentang ketegasan. Inti pokok dari maksim pemufakatan adalah "kurangilah ketidaksesuaian antara diri sendiri dan orang lain // tingkatkanlah persesuaian antara diri sendiri dan orang lain.”. Berikut ini merupakan hasil analisis 
pelanggaran maksim kebijaksanaan dan maksim pemufakatan yang terdapat pada data 010 .

\section{Data 010}

$\begin{array}{ll}\text { Pelanggan } & \text { : "Itu apa mbak yang diskon?" } \\ \text { Sales } & \text { :"Dari purbasari." } \\ \text { Pelanggan } & \text { : "Ini dari Bali? Lulur Bali?" } \\ \text { Sales } & \text { : "Lulur Bali Herborist. Nggak coba yang ini?" } \\ \text { Pelanggan } & \text { : "Sama aja kan mbak?" } \\ \text { Sales } & \text { :"Sama aja ibu, cuma aromanya aja yang beda." } \\ \text { Pelanggan } & \text { :"Mustika ratu sekarang mahal ya?" } \\ \text { Sales } & \text { : "Apa?" } \\ \text { Pelanggan } & \text { :"Mustika ratu sekarang mahal." } \\ \text { Sales } & \text { :"Iya." }\end{array}$

Konteks tuturan pada data di atas adalah seorang pelanggan yang menanyakan kepada seorang sales mengenai barang yang sedang promosi. Seorang sales berusaha menjawab pertanyaan dari pelanggan dengan memberikan informasi mengenai barang yang ditunjuk oleh pelanggan tersebut. Selain itu, sales tersebut juga memberikan pilihan kepada pelanggan dengan menawarkan barang lain dan memberikan informasi mengenai perbedaannya. Pelanggan memperpanjang obrolan dengan menyebutkan satu merk yang dianggapnya semakin bertambah mahal, namun sales hanya menjawab singkat pertanyaan dari pelanggan tersebut tanpa memberikan penjelasan. Dialog ini berlangsung pada tanggal 10 Oktober 2016 pukul 19.06 WIB.

Interpretasi dari tuturan di atas adalah terdapat pelanggaran prinsip kesopanan pada tuturan sales yang menyatakan "lulur bali herborist. Nggak coba yang ini?". Pertanyaan sales tersebut, merupakan sebuah penawaran yang dilakukannya terhadap pelanggan. Pernyataan tersebut dikatakan melanggaran prinsip kesopanan karena sales melakukan proses menciptakan tuturan atau dalam kata lain sales memunculkan tuturan baru yang berbeda tetapi masih ada kaitannya dengan tuturan sebelumnya (Nurlaksana, 2015 : 114). Sebelumnya, pelanggan sedang membahas mengenai salah satu merk lulur, tetapi respon dari sales justru memberikan merk lain hal ini ditunjukkan untuk melesapkan dialog sebelumnya. Pernyataan tersebut dikatakan melanggar sebuah prinsip kesopanan karena adanya pelanggaran maksim yakni maksim kebijaksanaan. Maksim kebijaksanaan merupakan maksim yang berbicara soal keuntungan dan kerugian. Keuntungan yang semestinya diberikan kepada lawan tutur dan kerugain yang sebaiknya diperkecil oleh penutur. Dalam hal ini, sales sebagai penutur justru 
memberikan kerugian bagi pelanggan atau lawan tuturnya. Kerugian yang ditimbulkan adalah sales memberikan merk lulur lain dengan harga yang lebih mahal serta kualitas dan perbedaan yang tidak terlalu berbeda dengan lulur yang sebelumnya sehingga pelanggan memperoleh kerugian berupa materi.

Kedua, pada dialog akhir dari tuturan data di atas, pada pertanyaan pelanggan yang bermaksud memberikan informasi kepada sales berupa perubahan harga, pelanggan memberikan pernyataan "mustika ratu sekarang mahal." yang kemudian dijawab singkat oleh sales dengan pernyataan "iya". Pernyataan singkat dari sales tersebut merupakan sebuah pelanggaran prinsip kesopanan yang mengacu pada pelanggaran maksim pemufakatan. Pernyataan singkat yang dituturkan oleh kasir untuk merespon pelanggan tersebut dinilai kurang sopan karena kasir tidak mempertanggunjawabkan pernyataannya tersebut. Hal yang sebaiknya dilakukan oleh kasir adalah memberikan alasan terhadap pernyataannya tersebut dengan mengungkapkan alasan mengapa harga barang yang dimaksud oleh pelanggan tersebut mengalami kenaikan harga yang sangat tinggi.

\section{Pelanggaran Maksim Pemufakatan}

Menurut Leech (dalam tarigan 2015 : 36). Maksim pemufakatan adalah maksim yang berbicara tentang ketegasan. Inti pokok dari maksim pemufakatan adalah "kurangilah ketidaksesuaian antara diri sendiri dan orang lain // tingkatkanlah persesuaian antara diri sendiri dan orang lain.”. Berikut ini merupakan hasil analisis pelanggaran maksim pemufakatan yang terdapat pada data 011 .

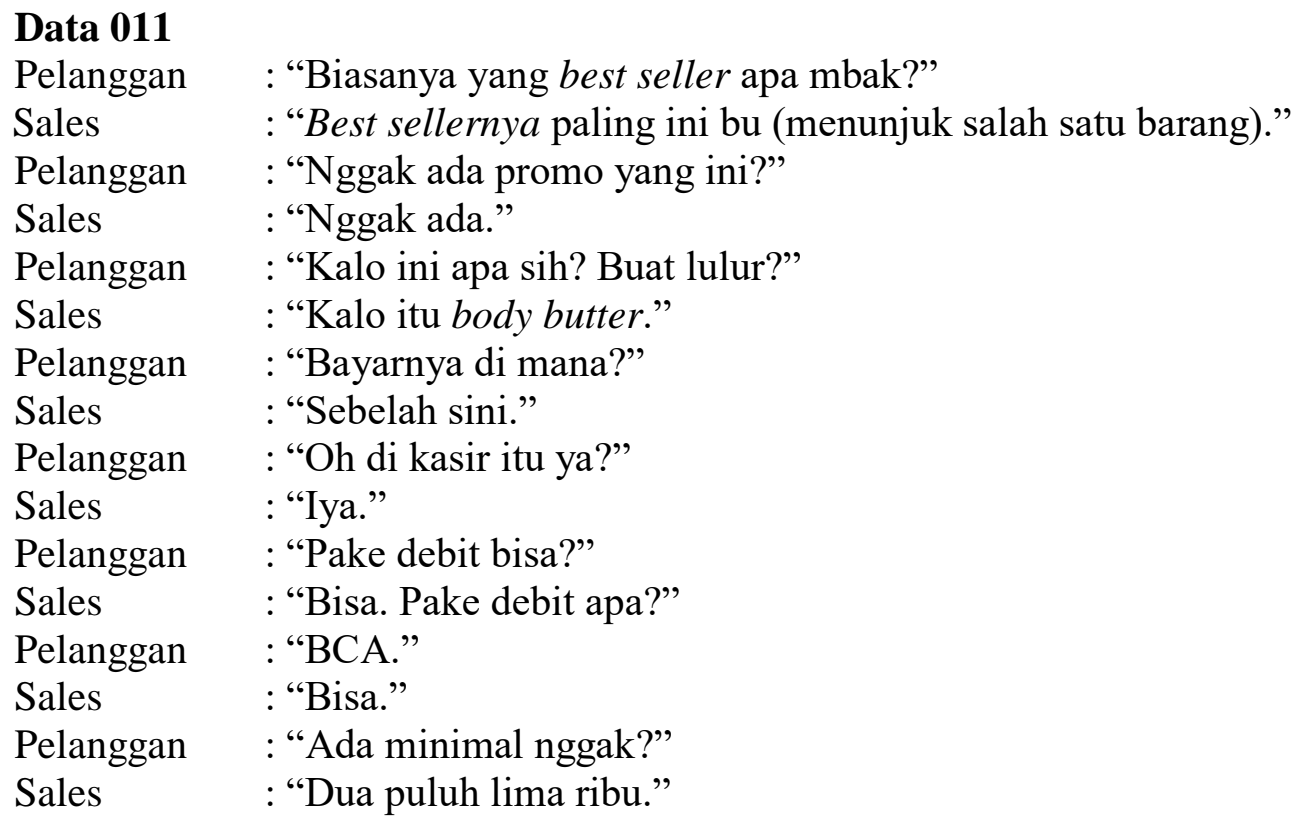


Konteks tuturan pada data di atas adalah seorang pelanggan yang menanyakan tentang barang yang banyak diminati oleh pelanggan lain atau dalam kategori penjualan terbanyak. Sales memberikan jawaban dengan menunjuk salah satu barang, kemudian pelanggan menanyakan tentang promosi barang yang ditunjuk oleh sales tersebut namun ternyata sedang tidak ada promosi untuk barang tersebut. Selanjutnya, pelanggan menanyakan fungsi dari barang lain yang ditunjuk oleh pelanggan dan sales menjawab pertanyaan dari pelanggan tersebut. Kemudian pelanggan tersebut menanyakan tempat pembayaran belanjaannya dan menanyakan penggunaan kartu debit yang selanjutnya dijelaskan oleh sales mengenai tempat pembayaran dan penggunaan kartu debit. Dialog ini terjadi pada tanggal 10 Oktober 2016 pukul 19.07 WIB.

Interpretasi terhadap tuturan pada data di atas, memberikan asumsi adanya pelanggaran prinsip kesopanan yang dilakukan oleh seorang sales. Pertama, pada tuturan sales yang menyatakan "nggak ada.". Pernyataan tersebut merupakan jawaban dari pertanyaan dari pelanggan mengenai program promosi diskon terhadap barang yang ditunjuk. Pada pernyataan sales tersebut dikatakan melanggar prinsip kesopanan karena pernyataan tersebut bersifat singkat dan tidak dapat memberikan alasan terhadap pernyataannya tersebut. Selain itu, pernyatan tersebut juga melanggar maksim pemufakatan. Dikatakan melanggar maksim pemufakatan karena sales tidak dapat memberikan alasan terhadap pernyatannya tersebut atau dapat dikatakan sales tidak dapat memberikan pertanggungjawaban atas pernyataannya. Hal yang sebaiknya dilakukan oleh sales tersebut adalah dengan memberikan alasan mengapa barang yang ditunjuk oleh pelanggan tersebut tidak ada program diskon atau sales dapat memberikan saran untuk memilih barang lain yang sedang ada promosi diskon.

Selain dari pelanggaran maksim, hal yang menjadi adanya pelanggaran prinsip kesopanan adalah adanya ketidaktepatan penggunaan kata atau bahasa. Pada pernyataan "best sellernya paling ini bu." Penggunaan kata "paling" yang diucapkan oleh sales tersebut menimbulkan adanya ketidakyakinan terhadap pernyataannya. Penggunaan kata "paling" dapat diganti dengan kata "yang" untuk menimbulkan efek lebih sopan dan lebih meyakinkan pelanggan. Selanjutnya, pada pernyataan "kalo itu body butter." Penggunaan kata itu, terkesan tidak sopan karena, kata "itu" menunjukkan adanya kemalasan sales untuk menunjukkan barang yang dimaksud oleh pelanggan. Tindakan yang seharusnya dilakukan oleh sales agar terkesan lebih sopan adalah dengan 
mengambil barang yang dimaksud dan menggunakan pernyataan "kalau yang ini body butter ibu fungsinya sama dengan body lotion tetapi body butter lebih terasa lembab di kulit.". Tindakan menginformasikan atau menyarankan adalah tindakan yang tepat untuk tidak penyelamatan wajah.

\section{Pelanggaran Maksim Kesederhanaan}

Menurut Leech (dalam Tarigan, 2015 : 36), maksim kesederhanaan adalah maksim yang berbicara tentang ekspresi dan asersi. Inti pokok dari maksim kesederhanaan adalah "kurangilah pujian pada diri sendiri // tambahilah cacian pada diri sendiri.". Berikut ini merupakan hasil analisis pelanggaran maksim kesederhanaan yang terdapat pada data 012 .

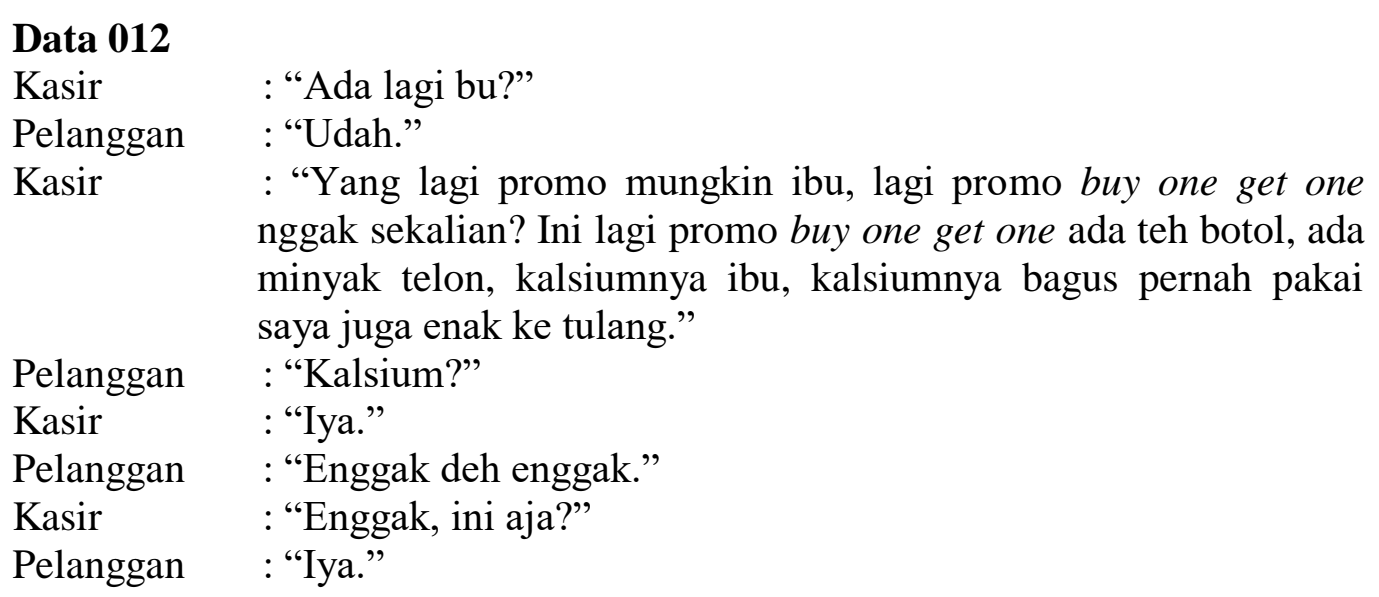

Konteks tuturan pada data di atas adalah seorang pelanggan yang bermaksud membayarkan belanjaannya ke kasir, kemudian kasir memberikan penawaran promosi yang sedang berjalan pada hari itu dengan menyebutkan beberapa barang kepada pelanggan tersebut. Setelah kasir memberikan penawaran promosi, pelanggan memberikan penolakan terhadap penawaran kasir tersebut dan menyudahi proses belanjanya. Dialog ini terjadi pada tanggal 12 Oktober 2016 pada pukul 20.30 WIB.

Interpretasi terhadap dialog pada data di atas, terdapat beberapa pelanggaran prinsip kesopanan yang dilakukan oleh kasir terhadap pelanggan. pertama, pada pernyataan kasir yang menyatakan "ada lagi bu?". Pernyataan tersebut merupakan proses awal dialog di mana pertama kalinya adanya interaksi antara kasir dengan pelanggan. Pernyataan tersebut dikatakan sebagai sebuah pelanggaran prinsip kesopanan karena kasir tidak melakukan proses awal pembuka dialog seperti ucapan 
salam. Ucapan salam atau sapaan pertama dikatakan penting dilakukan oleh seorang kasir karena hal tersebut masuk ke dalam standar operasional kerja, selain itu, dengan adanya ucapan salam yang dilakukan oleh seseorang yang baru kenal atau baru bertemu menunjukkan adanya sikap ramah dan sopan dari seseorang itu sendiri terlebih jika ia adalah seorang pelayan atau kasir. Dalam hal ini, kasir tidak memberikan salam sapaan kepada pelanggannya hal tersebut akan menimbulkan asumsi akan sikap dari kasir itu sendiri yang terlihat kurang sopan.

Selanjutnya, pada pernyataan kasir yang menuturkan "yang lagi promo mungkin ibu, lagi promo buy one get one nggak sekalian? Ini lagi promo buy one get one, ada teh botol, ada minyak telon, kalsiumnya ibu, kalsiumnya bagus pernah pakai saya juga enak ke tulang.". Pernyataan tersebut dikatakan sebagai tindakan menyarankan kepada pelanggan. Tuturan kasir tersebut dikatakan melanggar prinsip kesopanan karena, pertama, kasir menggunakan kalimat yang diulang-ulang seperti pada frasa "lagi promo buy one get one" yang diulang sebanyak tiga kali. Tindakan tersebut bertujuan untuk mempertegas pelanggan mengenai program promosi yang berjalan, namun dengan diulangnya tuturan tersebut pelanggan akan menanggapi bahwa seorang kasir tersebut bertindak sebagai suatu pemaksa terhadap apa yang disampaikan. Selain itu, tuturan tersebut juga menggunakan kata yang tidak tepat seperti kata "lagi" yang seharusnya lebih sopan jika menggunakan kata "sedang" karena mengingat bahwa dalam suatu pelayanan formal maka harus digunakan bahasa yang formal.

Selanjutnya, terdapat tuturan kasir yang bersifat menyombongkan diri yang terdapat pada kalimat "kalsiumnya bagus pernah pakai saya juga enak ke tulang." Tuturan tersebut bermaksud agar pelanggan tertarik untuk membeli barang yang dimaksud oleh kasir tersebut dengan memberikan contoh kepada dirinya yang telah mencoba mengkonsumsi barang tersebut, namun dalam hal ini kasir terkesan menyombongkan diri mengingat bahwa harga kalsium yang ditrawarkan tersebut memiliki nilai harga yang mahal secara tidak langsung kasir ini melakukan pelanggaran maksim kesederhanaan. Dalam hal ini, kasir melakukan tindakan yang justru bersifat memuji diri sendiri dengan menyombongkan bahwa ia mampu untuk membeli kalsium dengan harga yang relatif mahal. Sedangkan efek perasaan yang timbul dalam diri pelanggan tersebut adalah pelanggan akan merasa direndahkan oleh kasir tersebut 
karena merasa tidak mampu untuk membeli kalsium tersebut meskipun pada konteks yang sebenarnya tidak seperti kejadian yang sebenarnya.

Selanjutnya pada tuturan kasir "enggak ini aja?” yang merupakan pertanyaan ulang dari kasir yang bermaksud menanyakan tambahan belanjaan pelanggan. Tuturan tersebut dikatakan melanggar prinsip kesopanan karena penggunaan kata yang tidak sesuai dengan yang seharusnya diujarkan oleh kasir tersebut. pada tuturan sebelumnya, kasir tersebut menawarkan kepada pelanggan program promosi untuk beberapa barang yang telah disebutkan oleh kasir, namun penawaran tersebut ditolak oleh pelanggan tersebut dengan tuturan "enggak deh enggak." Penggunaan kata "enggak" yang juga diujarkan oleh kasir dinilai kurang tepat digunakan dalam hal pelayanan karena terdengar kurang sopan dan merupakan kata non formal. Kasir dapat mengganti kata "enggak" dengan kata "cukup" agar terkesan lebih sopan dan menghargai.

\section{E. Penutup}

Berdasarkan hasil analisis, dapat disimpulkan bahwa tuturan para karyawan Hero Supermarket Emerald Bintaro masih perlu banyak pembenahan khususnya dalam melakukan sebuah interaksi dengan pelanggan. Berdasarkan percakapan karyawan Hero Supermarket Emerald Bintaro terhadap pelanggan mengandung pelanggaran prinsip kesopanan yang dipengaruhi oleh ketidaktepatan pemilihan kata, ketimpangan informasi, kelebihan informasi yang disampaikan, dan pelanggaran maksim yang diantaranya maksim kebijaksanaan sebanyak tujuh data. Strategi yang paling banyak disarankan guna menyempurnakan adanya sebuah pelayanan. Strategi tersebut diantaranya menggunakan kata tanya dalam sebuah tindakan menawarkan, selain kata tanya, pelayan dapat menggunakan sebuah tindakan langsung atau menggunakan bahan pembanding dalam melakukan sebuah tindakan penawaran. Selanjutnya, pelanggan dapat menggunakan kalimat berita yang padat akan informasi namun bersifat cukup, tidak kurang dan tidak melebihkan informasi.

\section{F. Daftar Pustaka}

Ardianto, Wibi Kusuma. 2014. Pelanggaran Prinsip Kesopanan Dalam Acara Show Imah di Trans TV. Surakarta: Universitas Sebelas Maret.

Brown, Gillian dan George Yule. 1996. Analisis Wacana. Jakarta: Gramedia Pustaka. 
Lingua Rima: Jurnal Pendidikan Program Studi Bahasa dan Sastra Indonesia Vol. 7 No. 1 Januari 2018

Tarigan, Henry Guntur. 2009. Pengajaran Pragmatik. Bandung: Angkasa. 2015. Pengajaran Pragmatik. Bandung: Angkasa.

Yule, George. 2014. Pragmatik. Yogyakarta: Pustaka Pelajar 